\title{
Effectiveness of Occlusal Splints with Low-Level Laser Therapy on Anterior Disc Displacement of The Temporomandibular Joint
}

\author{
Loai M Abdelhay" ${ }^{* 1}$, Mansour M Hussein*, Atef M Hassaneen*
}

Codex : 02/2021/04

Aadj@azhar.edu.eg

\section{KEYWORDS}

TMJ, low-level laser therapy, anterior disc displacement, anterior repositioning splint, MRI

1. Department of Oral and Maxillofacial Surgery, Faculty of Dental Medicine, (Cairo, boys), Al-Azhar University, Egypt.

* Corresponding Author e-mail:

* loaimohammed142@azhar.edu.eg

\begin{abstract}
Aim: This study was designed to evaluate and compare between the using of oral appliance therapy alone and using of oral appliance with laser therapy for management of anterior disc displacement of the temporomandibular joint. Subjects and methods: randomized clinical study was done on 18 patients complaining of TMJ Anterior disc displacement. They were divided into 2 equal groups. Group A:occlusal appliance group Those patients worn the hard acrylic occlusal appliance covering the maxillary teeth (anterior repositioning splint) at night for two months. Group B: laser therapy group Those patients worn the hard acrylic occlusal appliance covering the maxillary teeth (anterior repositioning splint) at night and receive laser applications on the region of temporalis muscle, masseter muscle and mandibular condyle three times a week for 4 weeks. Full clinical TMJ examination was done at 0 baseline, one week, one month and two months postoperatively. The examination was done to evaluate T.M.J pain intensity by (VAS), TMJ clicking Sounds and Maximum mouth opening .Magnetic resonance imaging(MRI) performed before and after treatment period. Results: There was high percentage of improvement in all symptoms of anterior disc displacement either with or without reduction by using of double action of splint and laser rather than the improvement by using splint only. Conclusion: The using of splint only is acceptable and successful but the using of the laser with splint is better and more successful in treatment of the patients complained from anterior disc displacement of the temporomandibular joint.
\end{abstract}

\section{INTRODUCTION}

Internal derangement in temporomandibular joint (TMJ) is a common dysfunction of the stomatognathic system. The most common type is disc displacement with reduction characterized by clicking in the temporomandibular joint.in about 5\% of cases the disc displacement without reduction with limited mouth opening is observed. The main symptoms of anterior disc displacement with reduction are pain in affected joint and decreased range of mouth opening $(\leq 35 \mathrm{~mm})$, which deteriorate the function of the stomatognathic system and force the patient to look for professional help ${ }^{(1)}$. 
The goal of treatment for anterior disc displacement is the elimination or reduction of pain and joint sounds and a return to normal TMJ function. The treatment of disc displacement involves a diet of soft foods, behaviour modification, pharmacotherapy, inter-occlusal splints, intra-articular injections, physical therapy ,arthrocentesis, arthroscopy, and open joint surgery. In recent years, low-level laser therapy (LLLT) has been introduced as a noninvasive physical method for the treatment of disc displacement and myofascial pain ${ }^{(2)}$.

The presence of any occlusal appliance leads to stress reduction in the temporomandibular joint secondary to change in the position of the mandible and decreased muscle activity. There are 3types of occlusal appliances commonly used in the therapy of displaced disc with reduction stabilization ,distraction and anterior repositioning splints. The aim of anterior repositioning splint is to reestablish physiological disc-condyle relationship ${ }^{(3)}$.

Recently Low level laser therapy (LLLT) has been investigated and used clinically in the treatment of a variety of acute and chronic musculoskeletal injuries, degenerative conditions and wound healing for about 20 years. The basic effects of LLLT are bio-stimulative, regenerative, analgesic and antiinflammatory ${ }^{(4)}$.

Study hypothesis:The presnt study could be of a significant value on using laser and anterior repositioning splint for treatment of anterior disc displacement.

\section{SUBJECTS AND METHODS}

Eighteen Patients were randomly selected from those attending the outpatient clinic of the Oral and Maxillofacial Surgery Department Faculty of Dental Medicine Al-Azhar University,Boys ,Cairo and AL Sayed Galal Hospital. They were complaining of TMJ Anterior disc displacement.
Study design was randomized clinical study. Inclusion criteria:Patients with a diagnostic criteria for unilateral and bilateral temporomandibular disorders as clicking and tempromandibular pain ,Both sexes and Age from 20 to 50 years.Exclusion criteria: Presence of a known connective tissue or autoimmune disease, Patients with history of TMJ surgery ,Patients with degenerative disease or osteoarthritis .Patients with history of major jaw trauma ,Patient with dentofacial deformity.The patients were randomly allocated into two groups:

- Group A:occlusal appliance group (OA): 9 patients worn the hard acrylic occlusal appliance covering the maxillary teeth (anterior repositioning splint) at night for two months.

- $\quad$ Group B: laser therapy group(LT):9 patients worn the hard acrylic occlusal appliance covering the maxillary teeth (anterior repositioning splint) at night and receive laser applications on the region of temporalis muscle, masseter muscle and mandibular condyle three times a week for 4 weeks.

All the patients matched the inclusion criteria were subjected to:

\section{i. Full history taking:}

Medical history and any trauma history were taken and the clinical examination was recorded for each patient.

\section{i. Full clinical TMJ examination:}

The clinical examination was done at 0 baseline, one week, one month and two months postoperatively. The following key parameters were evaluated as follows:

1. Assessment of T.M.J pain intensity by (VAS): Patients were asked to mark their pain level on visual analogue scale (VAS). The VAS was measured on a $10-\mathrm{mm}$ scale with "absence of pain; $0=$ no pain " and "worst pain in my life; $10=$ severe pain "as the extremes. 
2. Assessment of TMJ clicking Sounds: Auscultation of the TMJs during opening and closing of the mandible for clicking or crepitus The patient was asked to open his/her mouth as wide as possible. Once an opening clicking sound was detected, it was recorded by the dentist. Joint noises were recorded as (clicking, crepitus or none).

Assessment of Maximum mouth opening (MMO): Inter-incisal distance was recorded in millimeter by measuring the vertical distance between the middle of the incisal edges of the upper and lower central incisors.

\section{ii. Radiological examination:}

Magnetic resonance imaging(MRI) confirmed the anterior displacement of the TMD bilaterally at the same time. This was done at Al-Sayed Galal hospital.Evaluation of MRI images was based on the location of the disc relative to the condyle in the parasagittal image Fig(1).

The MRI images were taken using a magnetic resonance tomograph (1.5 Tesla) (MAGNETOM Symphony; Siemens, Erlangen, Germany) in combination with bilateral TMJ surface coils (double ring array coil; Siemens, Erlangen, Germany) featuring SE (spin echo) sequences (T1-weighted, proton density- (PD-) weighted, or T2-weighted; 5 to 7 slices; $3 \mathrm{~mm}$ slice thickness). The imaging was done without using contrast media.

\section{iii. Anterior repositiong splints placement}

The maxillary and mandibular full arch alginate impressions were made in metal trays. The impressions poured with extra hard stone to ensure accurate reproduction of surface details. The casts were left to dry ,Recording jaw relations The initial wax construction bite was taken by advancing the mandible to an incisal edge-to-edge position and achieve a Class III or super Class III molar relationship with a $5 \mathrm{~mm}$ vertical opening in the premolars region. Then casts mounted on the articulator, waxing ,curing finishing and delivery Patients were instructed to wear the appliance at night for 8 weeks. They were told not to chew on the splint, and advised to reduce para function and avoid hard bites.

\section{iv. Low level laser protocol:}

All patients were treated with 12 sessions of LLLT.CDHC DenLase 980/7Diode Laser Therapy System, a Class IV laser product, producingsemiconductive (diodic) gallium arsenide (GaAs) laser (input: $5 \mathrm{~V}-14$ A,visible output: $1 \mathrm{~mW} \max @$ 630-670 nm, invisible output: 7 W max @800-990 nm manufactured by China Daheng Group Inc.) Was utilized in the study was used.

LLLT (wavelength: $904 \mathrm{~nm}$, mean output power: $0.6 \mathrm{~W}$, duration: $60 \mathrm{~s}$, dosage: $4 \mathrm{~J} / \mathrm{cm} 2$ ) was applied to all the tender points selected during examination. The subjects and the clinician used protective eyewear. The therapeutic LLLT application was achieved through direct contact of the probe on the skin. The laser beam was delivered through a handheld single laser probe.
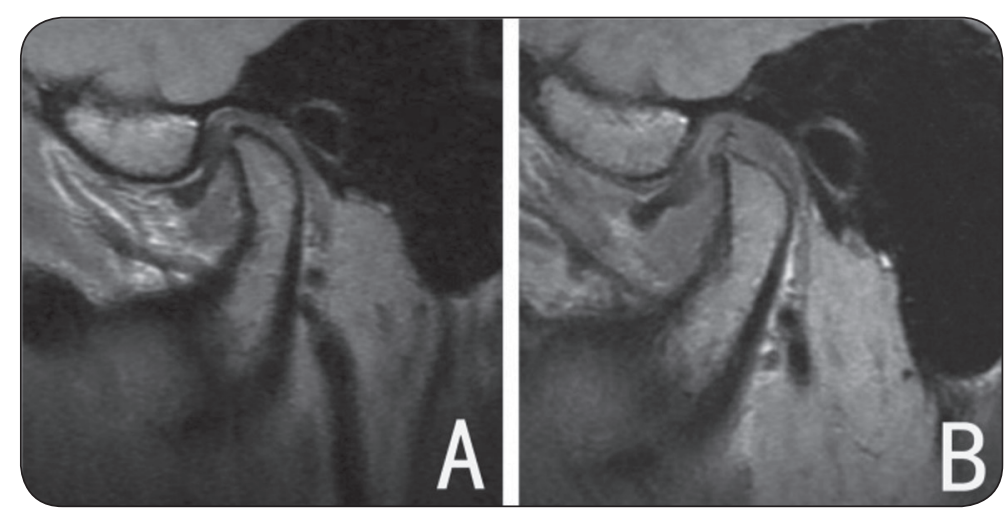

Fig. (1) MRI showing Joint with poor outcome. (A) DDwR before treatment; (B) the disc was not captured after treatment. 
The probe was placed perpendicular directly on the skin behind, in front of, and above the joint area. It was also applied over the painful muscle spots (tender points) like masseter, temporalis.

\section{RESULTS}

\section{Statistical analysis}

Data were fed to the computer and analyzed using IBM SPSS software package version 20.0.

\section{Clinical evaluation}

\section{1- Joint pain}

Both groups; showed a statistically significant decrease in mean of pain score Laser group showed more decrease in pain score compared to splint group either during function or rest stat in patient with ADDWR and ADDWOR (tab. 1,2,3,4).

Table (1) The changes in VSA (pain score) in patient suffered from ADDWR at Function before and after treatment

\begin{tabular}{|c|c|c|c|c|}
\hline Time & \multicolumn{2}{|c|}{ Mean } & \multicolumn{2}{c|}{ SE } \\
\hline Preoperative & \multicolumn{2}{|c|}{8.08} & \multicolumn{2}{c|}{ \pm 0.26} \\
\hline \multirow{2}{*}{ Treatment } & \multicolumn{2}{|c|}{ Splint without laser } & \multicolumn{2}{c|}{ Splint with laser } \\
\cline { 2 - 5 } & Mean & SE & Mean & SE \\
\hline One week & 6.38 & \pm 0.33 & 5.21 & \pm 0.34 \\
\hline One month & 5.11 & \pm 0.27 & 3.68 & \pm 0.38 \\
\hline Two months & 4.70 & \pm 0.21 & 2.92 & \pm 0.25 \\
\hline
\end{tabular}

Table (2): The changes in VAS (pain score) in patient suffered from ADDWR at rest before and after treatment

\begin{tabular}{|l|c|c|c|c|}
\hline \multicolumn{1}{|c|}{ Time } & \multicolumn{2}{c|}{ Mean } & \multicolumn{2}{c|}{ SE } \\
\hline Preoperative & \multicolumn{2}{|c|}{4.88} & \multicolumn{2}{c|}{ \pm 0.26} \\
\hline \multirow{2}{*}{ Treatment } & \multicolumn{2}{|c|}{ Splint without laser } & \multicolumn{2}{c|}{ Splint with laser } \\
\cline { 2 - 5 } & Mean & SE & Mean & SE \\
\hline One week & 3.86 & \pm 0.27 & 2.53 & \pm 0.22 \\
\hline One month & 3.19 & \pm 0.17 & 1.89 & \pm 0.13 \\
\hline Two months & 2.60 & \pm 0.22 & 0.88 & \pm 0.12 \\
\hline
\end{tabular}

Table (3): The changes in VSA (pain score) in patient suffered from ADDWOR at function before and after treatment

\begin{tabular}{|l|c|c|c|c|}
\hline \multicolumn{1}{|c|}{ Time } & \multicolumn{2}{c|}{ Mean } & \multicolumn{2}{c|}{ SE } \\
\hline Preoperative & \multicolumn{2}{|c|}{8.09} & \multicolumn{2}{c|}{ \pm 0.32} \\
\hline \multirow{2}{*}{ Treatment } & \multicolumn{2}{|c|}{ Splint without laser } & \multicolumn{2}{c|}{ Splint with laser } \\
\cline { 2 - 5 } & Mean & SE & Mean & SE \\
\hline One week & 7.26 & \pm 0.39 & 5.99 & \pm 0.47 \\
\hline One month & 6.61 & \pm 0.48 & 4.63 & \pm 0.46 \\
\hline Two months & 5.29 & \pm 0.39 & 3.13 & \pm 0.32 \\
\hline
\end{tabular}

Table (4): The changes in VSA (pain score) in patient suffered from ADDWOR at rest before and after treatment

\begin{tabular}{|l|c|c|c|c|}
\hline \multicolumn{1}{|c|}{ Time } & \multicolumn{2}{c|}{ Mean } & \multicolumn{2}{c|}{ SE } \\
\hline Preoperative & \multicolumn{2}{|c|}{6.39} & \multicolumn{2}{c|}{ \pm 0.32} \\
\hline \multirow{2}{*}{ Treatment } & \multicolumn{2}{|c|}{ Splint without laser } & \multicolumn{2}{c|}{ Splint with laser } \\
\cline { 2 - 5 } & Mean & SE & Mean & SE \\
\hline One week & 5.744 & \pm 0.33 & 4.41 & \pm 0.28 \\
\hline One month & 5.033 & \pm 0.36 & 3.32 & \pm 0.29 \\
\hline Two months & 4.46 & \pm 0.48 & 2.08 & \pm 0.24 \\
\hline
\end{tabular}

\section{Joint sound}

Both groups; showed a statistically significant decrease in mean joint sounds till 2 months. Laser group showed more decrease in joint sounds compared to splint group in ADDWR patients (tab. 5).

Table (5): The changes in joint sounds in patient suffered from ADDWR before and after treatment

\begin{tabular}{|l|c|c|c|c|}
\hline \multicolumn{1}{|c|}{ Time } & \multicolumn{2}{c|}{ Mean } & \multicolumn{2}{c|}{ SE } \\
\hline Preoperative & \multicolumn{2}{|c|}{1.94} & \multicolumn{2}{c|}{ \pm 0.03} \\
\hline \multirow{2}{*}{ Treatment } & \multicolumn{2}{|c|}{ Splint without laser } & \multicolumn{2}{c|}{ Splint with laser } \\
\cline { 2 - 6 } & Mean & SE & Mean & SE \\
\hline One week & 1.01 & \pm 0.08 & 0.74 & \pm 0.07 \\
\hline One month & 0.84 & \pm 0.06 & 0.46 & \pm 0.08 \\
\hline Two months & 0.80 & \pm 0.07 & 0.24 & \pm 0.05 \\
\hline
\end{tabular}




\section{Maximal active mouth opening}

Both groups; showed a statistically significant increase in mean of maximal mouth opening till 2 months. Laser group showed more increase in maximal mouth opening compared to splint group in ADDWR and ADDWOR patients (tab6,7).

Table (6): Mean of maximal mouth opening by ( $\mathrm{mm}$ ) in patient suffered from ADDWR before and after treatment

\begin{tabular}{|c|c|c|c|c|}
\hline Time & \multicolumn{2}{|c|}{ Mean } & \multicolumn{2}{c|}{ SE } \\
\hline Preoperative & \multicolumn{2}{|c|}{33.52} & \multicolumn{2}{c|}{ \pm 1.23} \\
\hline \multirow{2}{*}{ Treatment } & \multicolumn{2}{|c|}{ Splint without laser } & \multicolumn{2}{c|}{ Splint with laser } \\
\cline { 2 - 5 } & Mean & SE & Mean & SE \\
\hline One week & 37.53 & \pm 1.22 & 41.22 & \pm 0.87 \\
\hline One month & 38.38 & \pm 0.93 & 44.09 & \pm 0.62 \\
\hline Two months & 38.79 & \pm 1.08 & 47.33 & \pm 0.93 \\
\hline
\end{tabular}

Table (7): Mean of maximal mouth opening by (mm) in patient suffered from ADDWOR before and after treatment

\begin{tabular}{|l|c|c|c|c|}
\hline \multicolumn{1}{|c|}{ Time } & \multicolumn{2}{c|}{ Mean } & \multicolumn{2}{c|}{ SE } \\
\hline Preoperative & \multicolumn{2}{|c|}{27.35} & \multicolumn{2}{c|}{ \pm 0.52} \\
\hline \multirow{2}{*}{ Treatment } & \multicolumn{2}{|c|}{ Splint without laser } & \multicolumn{2}{c|}{ Splint with laser } \\
\cline { 2 - 5 } & Mean & SE & Mean & SE \\
\hline One week & 30.30 & \pm 1.04 & 38.74 & \pm 1.08 \\
\hline One month & 34.41 & \pm 1.16 & 41.99 & \pm 0.82 \\
\hline Two months & 36.46 & \pm 1.06 & 43.74 & \pm 1.25 \\
\hline
\end{tabular}

\section{DISCUSSION}

Anterior repositioning appliances are designed for treatment of patients with internal derangements of the TMJ.Protrusion of the mandible may decrease overload on the retrodiscal tissues, allowing adaptive changes to occur. Several studies have revealed the short-term efficacy of this modality for reducing TMD symptoms ${ }^{(5)}$, in agreement with our present results.
Full-time use of anterior repositioning appliances may be associated with adverse effects such as posterior open bite, occlusal alterations, and myostatic contracture of the inferior lateral pterygoid muscle ${ }^{(6)}$.In our present study, no such side effects were observed in the groups treated with splints after two months.

Okeson suggested that part-time use of an anterior positioning splint is the final definitive treatment for disc displacements and disc dislocations with reduction ${ }^{\left({ }^{6}\right)}$. As an anterior positioning splint can change the position of the mandible temporarily to enhance adaptation of the retrodiscal tissues with no side effects, this appliance was selected for the present study.

The use of the low-level laser has been suggested for the treatment of different myofascial and skeletal pain syndromes due to its anti-inflammatory and analgesic properties. It decreases muscle tension and regulates cellular activities ${ }^{(7)}$ In our study, the laser at a $940 \mathrm{~nm}$ wavelength was irradiated and it resulted in a significant reduction in pain in all the patients. The positive outcome of LLLT was demonstrated in previous studies by Salmos-Brito et $\mathrm{al}^{(7)}$ and Ebrahimi et al, ${ }^{(8)}$ who all found a significant reduction in pain intensity of TMD patients with LLLT.

Ismail et al, in their randomized study demonstrated that, as well as splint therapy, LLLT in combination with splint therapy was able to improve the VAS score and mandibular mobility of patients with ADD in agreement with our present study results ${ }^{(9)}$.

In the present study all patient's applied ARS then laser group only receive low level laser therapy which was used as adjunctive treatment with the splint for management of TMD.

The current study showed that ARS followed by LLLT decrease joint pain(VAS) in ADDWR \&ADDWOR. The double action of ARS and LLLT reducing pain more than if ARS used alone and this agree with studies of Schmitter et $\mathrm{al}^{(10)}$, Monglni et $\mathrm{al}^{(11)}$, Dowrkin S and Massoth DL ${ }^{(12)}$. 
In the present study, there was improvement in maximal mouth opening in ADDWR \&ADDWOR by using double action of ARS and LLLT, more than if the splint used alone and this agree with many studies of Stato et $\mathrm{al}^{(13)}$ and Lundth et $\mathrm{al}^{(14)}$.

In the present study there was an improvement in the joint sound in ADDWR by using a double action of ARS and LLLT more than the improvement when using ARS alone ,these results were compatible with the results of Simmons ${ }^{(15)}$ and Hosoki H et $\mathrm{al}^{(16)}$.

However there was no joint sound in case of ADDWOR before or after treatment.

\section{CONCLUSIONS}

From all previous results we can conclude that:

The using of anterior repositioning splint alone is acceptable and successful in reduction of ADD symptoms either with or without reduction. while the use of double action of low level laser and splint (ARS) is the better and more successful in reduction of ADD symptoms either with or without reduction.

\section{REFERENCES}

1. Carlson CR, Okeson JP, Falace DA, Nitz AJ, Curran SL, Anderson D. Comparison of psychologic and physiologic functioning between patients with masticatory muscle pain and matched controls. J Orofac Pain 1993;7.

2. Vasconcelos BC, Bessa-Nogueira RV, Rocha NS. Temporomandibular joint arthrocentesis: evaluation of results and review of the literature. Rev Bras Otorrinolaringol 2006;72

3. Wang X, Yang Z, Zhang W, Yi X, Liang C, Li X. Efficacy evaluation of low-level laser therapy on temporomandibular disorder. Hua Xi Kou Qiang Yi Xue Za Zhi 2011;29

4. Mazzetto MO, Hotta TH, Pizzo RC. Measurements of jaw movements and TMJ pain intensity in patients treated with GaA-1As laser. Braz Dent J 2010;21

5. Kalaykova S, Lobbezoo F and Naeije M. (2010): Two-year natural course of anterior disc displacement with reduction. J Orofac Pain;24(4):373-378.
6. Okeson JP. . Management of temporomadibular disorders and occlusion, Sixth edition, 2. St. Louis, MO: Mosby; 2008. 512 .

7. Salmos-Brito JA, de Menezes RF, Teixeira CE, Gonzaga RK, Rodrigues BH, Braz R. Evaluation of low-level laser therapy in patients with acute and chronic temporo mandibular disorders. Lasers Med Sci. 2013;28 (1):57-64. doi: 10.1007/s10103-012-1065-8.

8. Ebrahimi H, Najafi S, Khayamzadeh M, Zahedi A, Mahdavi A. Therapeutic and analgesic efficacy of laser in conjunction with pharmaceutical therapy for trigeminal neuralgia. J LasersMedSci.2018;9(1):63-68. doi:10.15171/jlms. 2018.13.

9. Ismail F, Demling A, Hessling K, Fink M, Stiesch-Scholz M (2007) Short-term efficacy of physical therapy compared to splint therapy in treatment of arthrogenous TMD. J Oral Rehabil 34, 807-813.

10. Schmitter M, Ohrbach R, Truelove E, Look J, Anderson G, Goulet JP, List T, Svensson P, Gonzalez Y, Lobbezoo F, Michelotti A, Brooks SL, Ceusters W, Drangsholt M, Ettlin D, Gaul C, Goldberg LJ, Haythornthwaite JA, Hollender L, Jensen R, John MT, Laat AD, Leeuw R, Maixner W, Meulen M, Murray G, Nixdorf DR, Palla S, Petersson A, Pionchon P, Smith B, Visscher CR, Zakrzewska J, Dworkin SF. Diagnostic Criteria for Temporomandibular Disorders (DC/TMD) for Clinical and Research Applications: recommendations of the Internation-al RDC/TMD Consortium Network and Orofacial Pain Special Interest Group. J Oral Facial Pain Headache 2014;28

11. Clark GT, Sakai S, Merrill R, Flack VF, McArthur D, et al. (1997): Waking and sleeping temporalis EMG levels in tension-type headache patients. J Orofac Pain;11(4):298-306.

12. Wilkes CH. (1989): Internal derangements of the temporomandibular joint. Pathological variations. Archives of Otolaryngology - Head \& Neck Surgery;115:469-477.

13. Stato $\mathrm{S}$,Kawamura ii and motigo K:management of nonreducing tempromandibular joint disc displacement.Evaluation of three treatments Oral Surg Oral Med 1995.80:384.

14. Lundth H, Westesson Pl, Eriksson L and Brooks SL: tempromandibular joint disc displacement.treatment with occlusal splint versus no treatment.Oral Surg 1992; 73:655-8.

15. Simmons HC (2005): 3rd; Board of Directors, American Academy of Craniofacial Pain. Guidelines for anterior repositioning appliance therapy for the management of craniofacial pain and TMD. Cranio.;23(4):300-305.

16. Hosoki H, Uemura S ,Petresson A and Rohli M:follow up examination of tempromandibular joint disc after splint therapy by MRI case report.J Cranio mandib disorder 1995;13:193-7. 


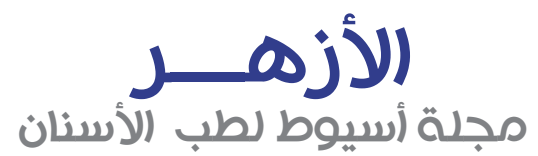

النشر الرسمي لكلية طب الأسنان جامعة الأزهر أسيوط الكاية

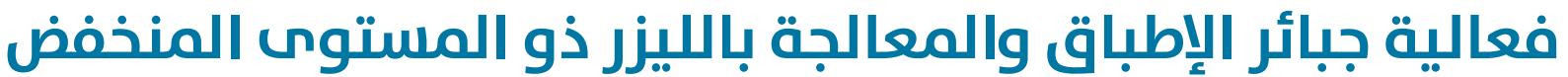

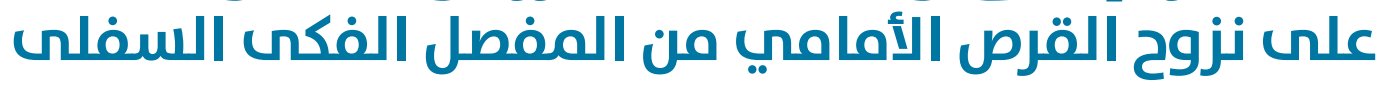

\author{
لؤى محمد عبلالحى *, منصور محمد حسين ,عاطف محمد حسنين \\ 1. قـسـم جـراحـة الفـم والوجـه والفكين، كلية طب الاسنان، ( القاهرة ربنين)، جـامعـة الازهر، مصر

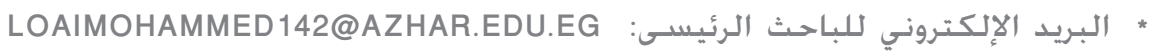

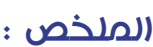

الهـدف: الغرض من الدراسـة هو تقييم تأثير الليزر منخفض المستوى كعلاج تكميلي مع جبيرة تغيير الموضع للأمام على المرضى الذين يعانون من الانزلاق الغضروفي الفرض من الدرامسي الاربّاعي وغير الارجّاعي.

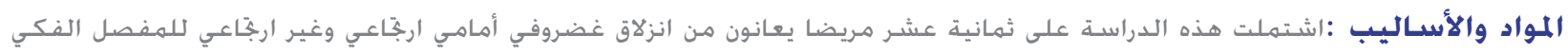

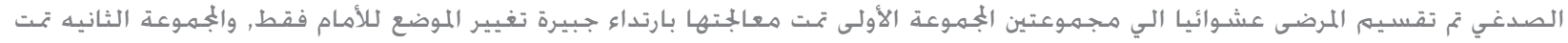

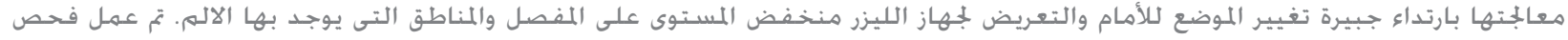

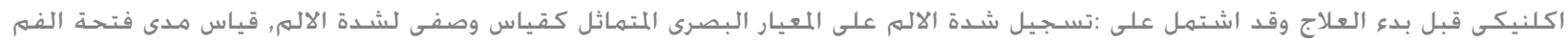

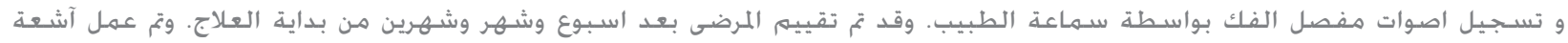
رنين مغناطيسي لمفصل الفك قبل البدء في العلاج وبعد الانتهاء منهـ.

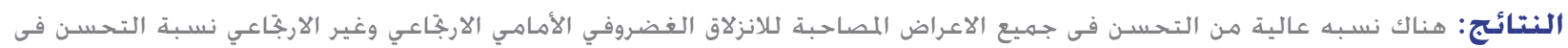
حالة استخـدام الليزر منخفض هن المستوى مع الجبيرة افضل بكثير من استخـدام الجبيرة بمفردها.

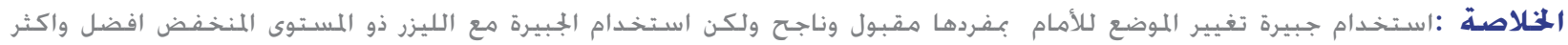

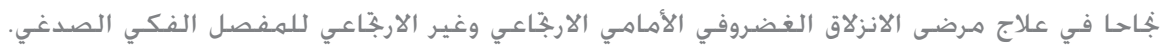

الكعلمات المفتاحية: المفصل الفكي الصدغي ,الليزر ذو المستوى المنخفض ,الانزلاق الغضروفي الأمامي , جبيرة تغيير الموضع للأهام, اشعهـ الرنين المغناطيسي 